\title{
The Self-Energized Credential System for the Plutonium Protection System
}

Thurlow W. H. Caffey, David E. Barnes

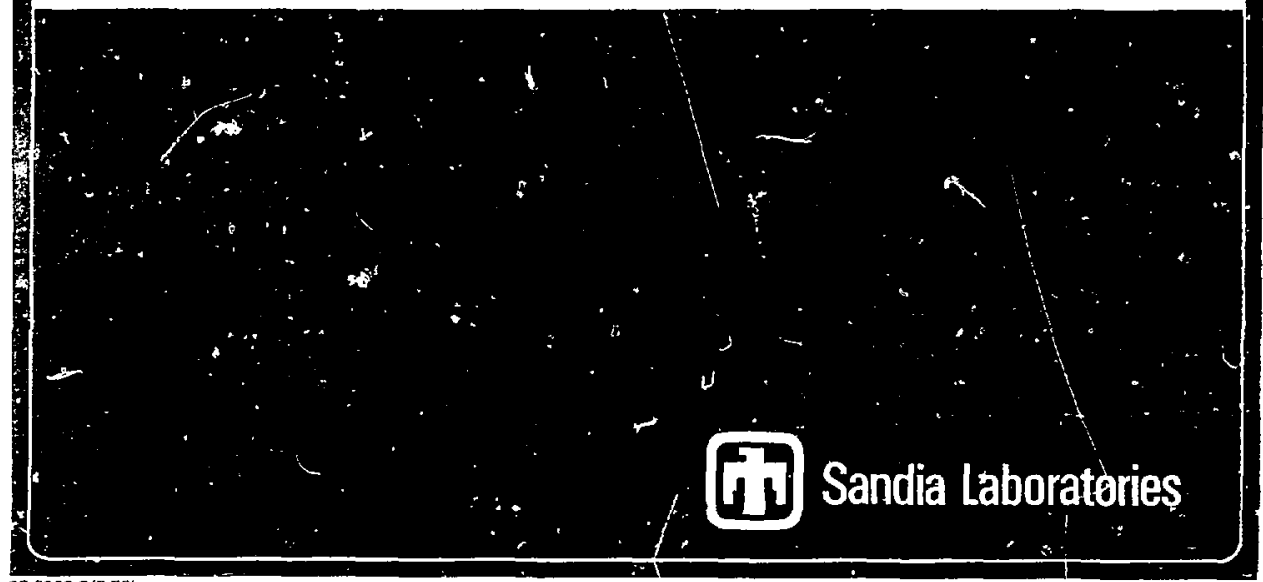




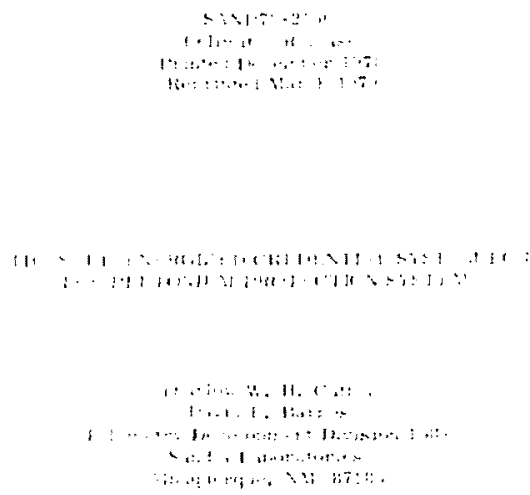

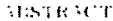

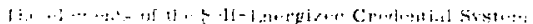

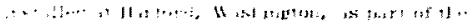

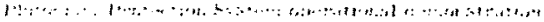

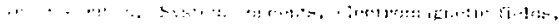

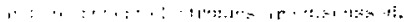

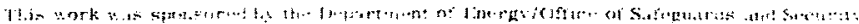

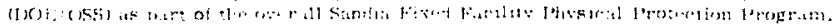




\section{CONTINTSS}

FORFW(MI)

System Jasecription

$\underline{[x}$

Conereft of Operution

Coding Considerations

Thysiological Lifferts

Portiłl Components

Jortal loops

110-kH\% Driver

t)iplexer

Fectronic Credential Reacler

Filter/Denodulator

Decoilur

Credential Components

flousing and Loop

Circuit Board

Code Storige and (it nreratior

APPISDL A -- Ambiguans Codes

APPLADLX B - Formulas for fnduced Volt3ge

APPINOLX C - Filter/Demodulator Tuning Procerlure

APPliXDLX D -- Josign of Credentiai Diplexer

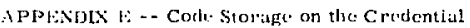




\section{It.A.TSTRAIIONS}

\begin{tabular}{|c|c|}
\hline ingur. & \\
\hline 1 & sitjos Componrents \\
\hline 2 & Corle. harueture. \\
\hline$\because$ & 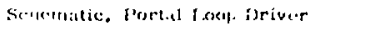 \\
\hline 4 & Sellematic, I,oop Jjellexer \\
\hline 3 & 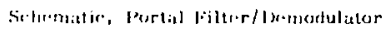 \\
\hline ; & Mlock isiagrim, inecodier \\
\hline$i$ & l:Iretronic Cordintial \\
\hline 8 & Jilantronic: Credtential Jlousing \\
\hline 9 & Srhematir, Self-linergizord Crerdential \\
\hline
\end{tabular}

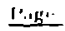

is

(1)

1:

14

If;

17

1 is

I)

20 


\section{YOR EWORD}

Developrent of the Self-Finurglaed Credentlal System (SLCS) was begun in lute 1976 snd thi. syatem w.ds ingt.1lerl at llanford, Washington, in early 1978. The system is distinguished by the iwo features that the credtntial is passive, and that the hearer does not have to altir naturial movi-ment in order to ust: the credential. The first feature makes the credential long lived, ind thi sccond makss it both unobtrusive and convenient.

The intended use of thi. SLCS is to monitor the passage of credentials into or out of a controllex are. It is assumed that the credential is being worn by the bearer to whom the creafential thas isbucd. Such an assumption is roasonable when the SfCS is used to enferce the salcety "Гwo-kian flul." in a hazamous work area, but the assumption must be verified by atuilialy means When the SECS is part of at pheicial security system.

Th. SFCS is userl at part of the plutonium Protection System (PPS) demonstration al Harford

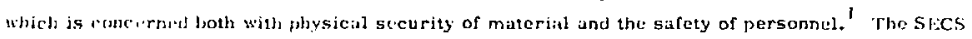

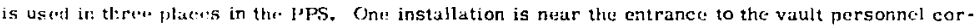

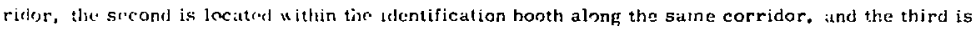

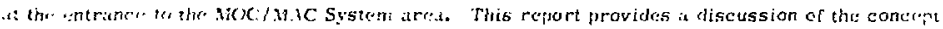

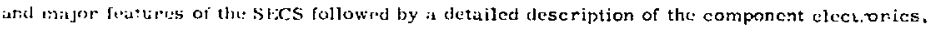




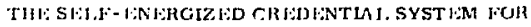

TII: PI.UTONIUM PFOT ICTION SYSTEM

\section{Sys:em Description}

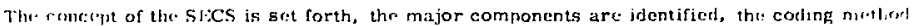
rxplained, ind the results of testing for the effects of the system upon heart pacemakers are sumIIitri\%tril.

\section{Cancept of Operition}

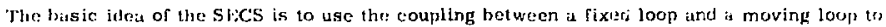

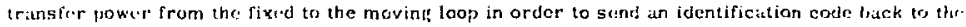
lixed loop. The fixed loop is litrge enough to provide a passageway through its intertor ur.t is mafi-rreis to as the "portal" loop. The moving loop is wound on a frame which contains a printest circuil cart on which the code is permanently starnd to form a credential. The portal loop trunsmits a continuous tone at $110 \mathrm{kI} \%$, and the credential transinits the cocte in bissts of a $55-k / 1$.

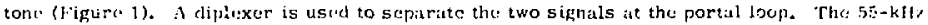
tone burst is amplified, converted to binury form in the decoder, and tested to ser if certuin formiat and parity conditions are met. If the binary code is validated, it is marle avilable- for transuissirn to itr operations center. Fach ol' the major comporents will. be treated fully in liater sections aiter two topies of overill interust art treated,

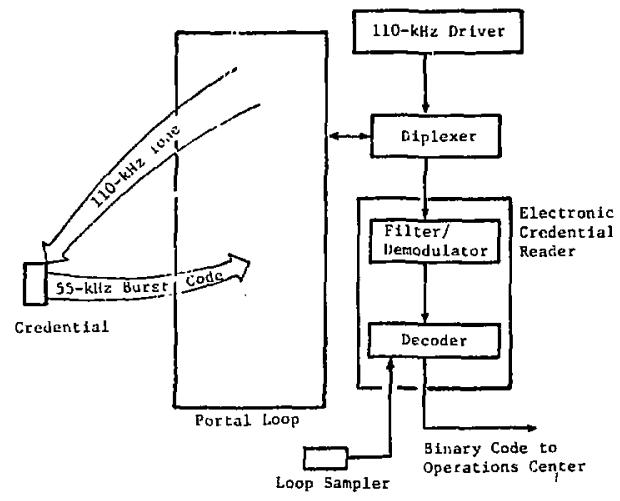

Tigure 1. Major Components 


\section{Corting Comsintartions}

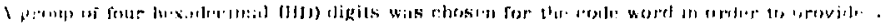

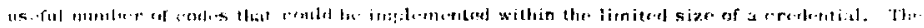

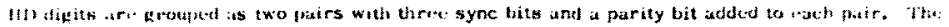

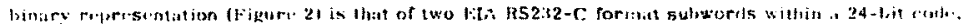

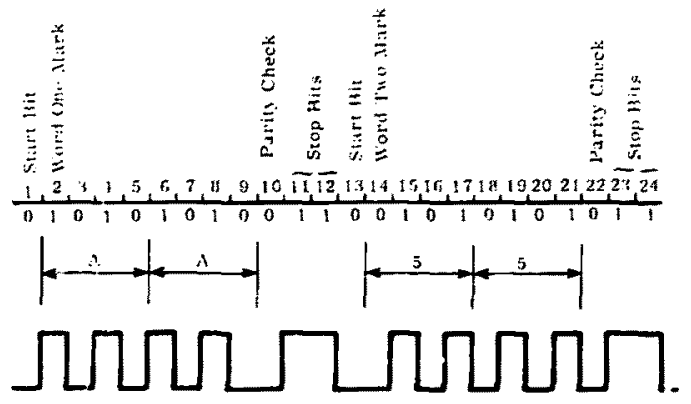

Figure: 2. Cow. Structure:

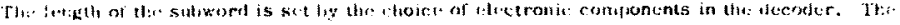

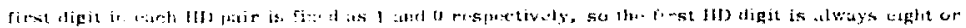

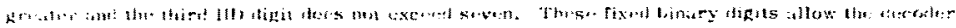

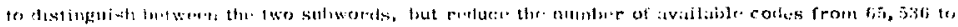

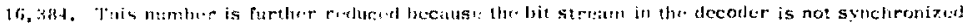

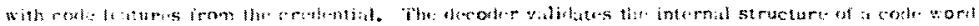

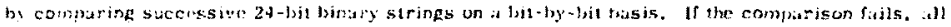

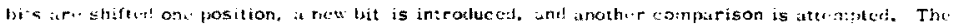

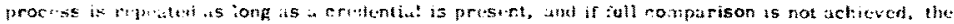

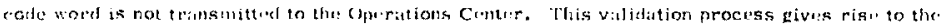

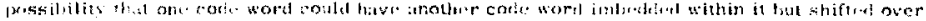

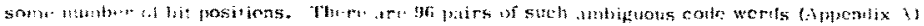

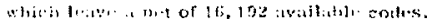




\section{Phasmlogis.al fiffects}

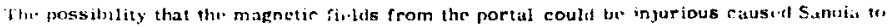

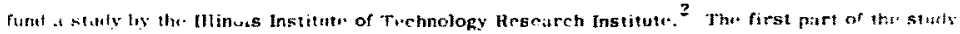

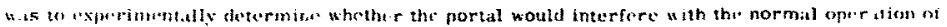

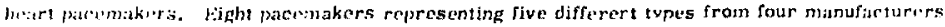

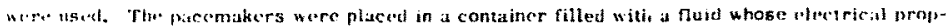

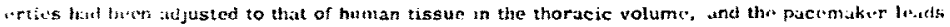

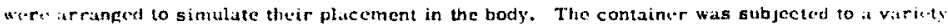
of stutic and anving tests within tice portal both with and without simulated carcliac witves, isfal

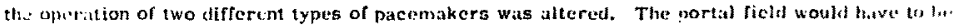
halvul. abproxinately, to climinate any possibility of interference. Conscrucntly, it is rerom-

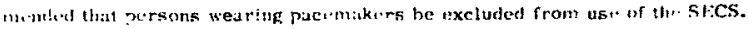

The second part of the study was a seurch through the literature of bialogical uffertsi tue to

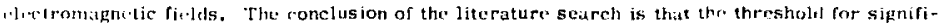

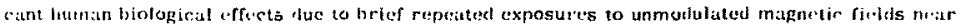

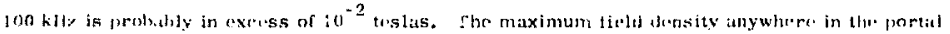

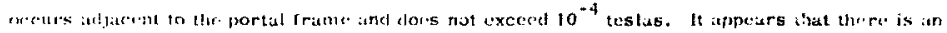

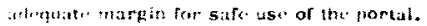

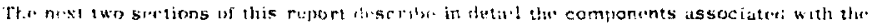

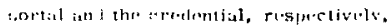

Portal Components

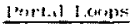

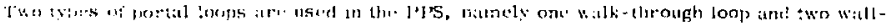

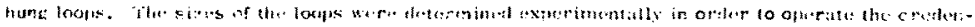

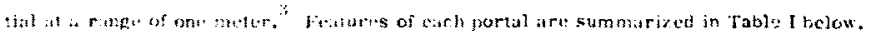

T:U1<I.t: I

l'ortit loop liseription

$\begin{array}{r}\text { I'ortil Typr .tht } \\ \text { Jotidion } \\ \hline\end{array}$

Wialk-through in bitull firsontul Curritor

Wibll llumg in Itherticication Pooth

Wall llung in MCOCl MC sysum Corrator i.eon Winding toimensions, $11 \times 1 W \times \Gamma(\mathrm{m})$

$1.98 \times 1.70 \times 0.027$

$1.10 \times 1.20 \times 0.090$

$1.10 \times 1.10 \times 0.090$

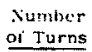

if

23

28
In-Situ Measureal Paramesters at $110 \mathrm{kHz}$

\begin{tabular}{|c|c|c|}
\hline $\begin{array}{l}\text { Induetialice } \\
(\mathrm{n} H \mathrm{H}) \\
\end{array}$ & $\underline{\theta}$ & $\begin{array}{c}\text { Podk } \\
\text { Imperess } \\
\end{array}$ \\
\hline 1.58 & 5.3 & 0.96 \\
\hline 2.90 & 41 & 0.61 \\
\hline 1. 60 & 67 & 1.2 \\
\hline
\end{tabular}




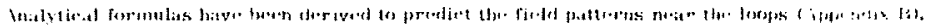

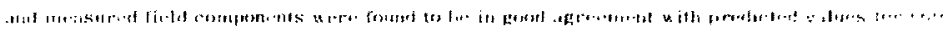

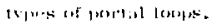

\section{$1101-1,11,1$ rerivir.}

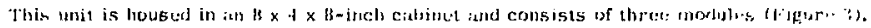

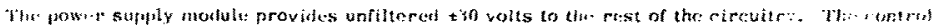

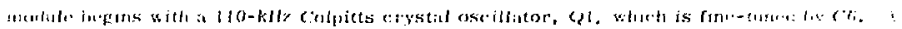

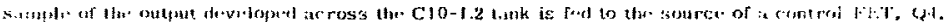

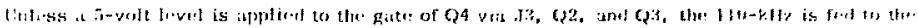

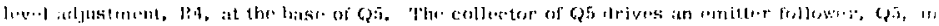

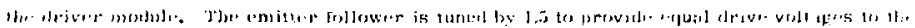

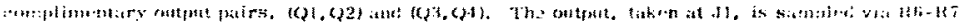

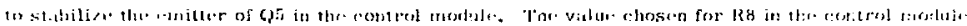

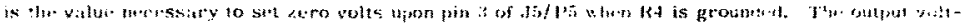

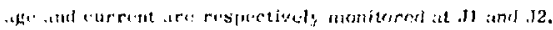

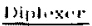

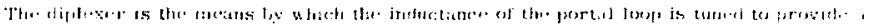

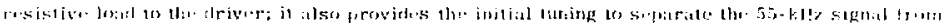

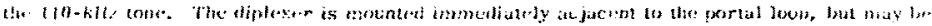
tom

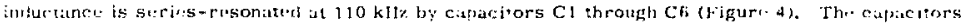

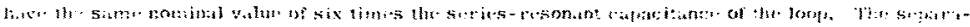

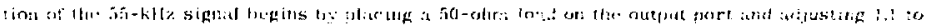

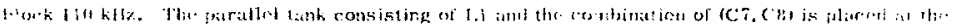

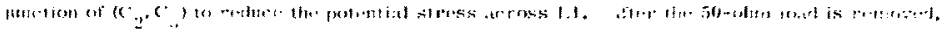

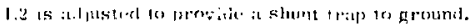




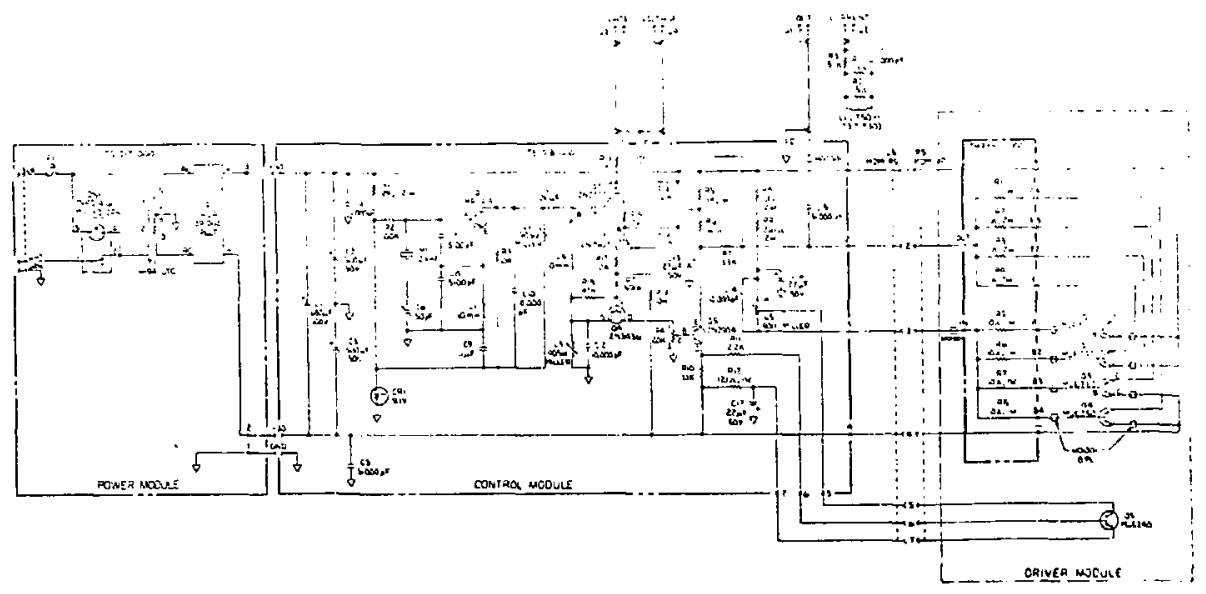

Figure $\therefore$. Schender, Port.1l I.oop Driver 


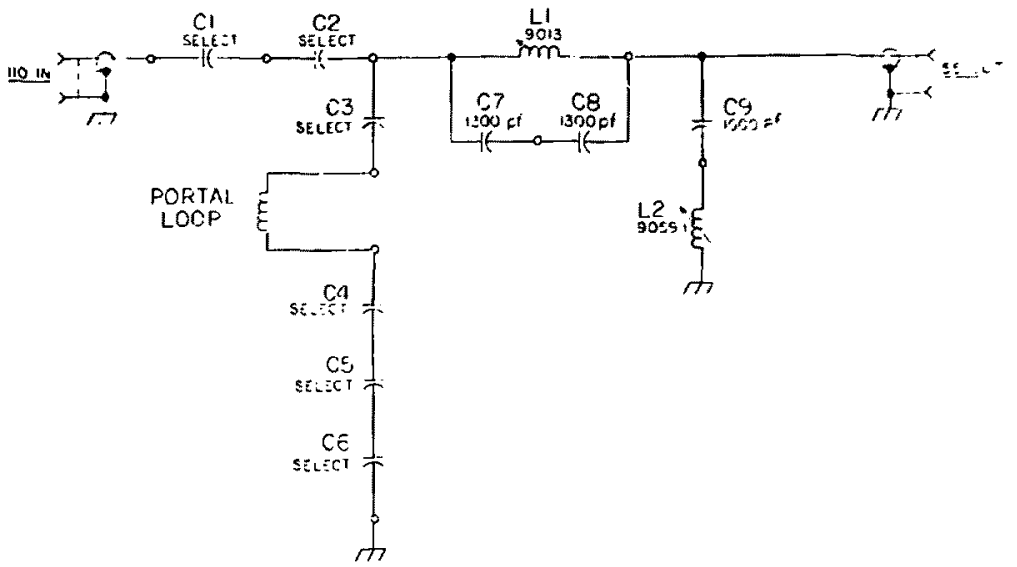

Figure 4. Schematic, Loop Diplexer 
This otundiard rack chassis, $5.25 \times 19 \times 19$ inches, provides 4 common powcr supply to sup-

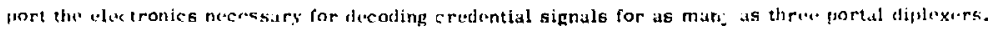

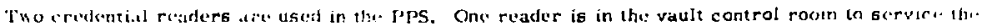

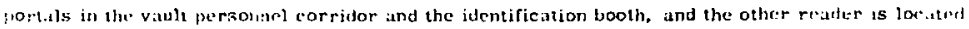

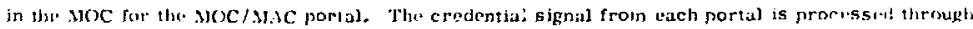
.t slpharate combination of filt.er/demodulator and duroder as explatined belox.

Fillir/Dinodulintor

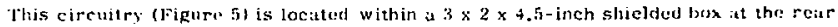

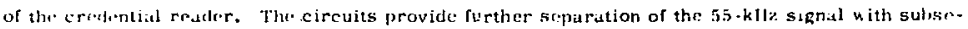

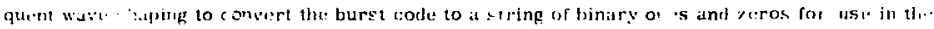
decoler.

The tumed rircuis at the input are isdusted (Appendix C) to further isolate the 5.5-kHe signial and include the effects of the rably from the diplexer. The outnut of the 100x amplifier, AR1, is

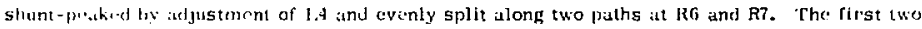
st.ats of ik2. and the low-pass filter which follows them, pravide a level which is proportional to the uwe of the peak of the postive signal envelope. Jill luvel is compared to the anne sifnisl in M12-3174 to wiminate noise lsursts which mily occur where binury aeros were intended in thr.

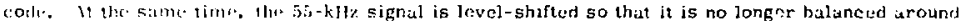
"reco but ringr.s frars 0 to 5 volts. This signai is used to trigger the monostable multivibrator in 1.1. innt, ihird signal modification which occurs in AR2-4 must now be uriderstood. A binary

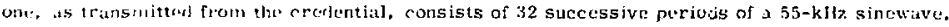
l'he rumpis rator action of AR2-A converts this to a succession of 32 pulsons with an individual pulse wirth of half the periof of a $55-\mathrm{kH}$. sinewave. This would also bn the output of $\mathrm{L} 1$, except that the combination of $\mathrm{R} 21$ and $\mathrm{C} 11$ provide a rotrigger which doos not allow the output or $\mathrm{L}$ ! to

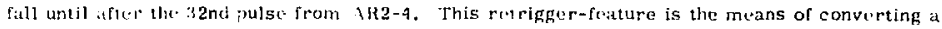
$55-k 11 \%$ burst into if pulst of comparable width and provides the desired binary ons. A nonzero output from L'1 to the 'ecrorler is prohibited unless the maan positive signal levil excecds the threshold sie by R14 it the input to \$R2-i. 


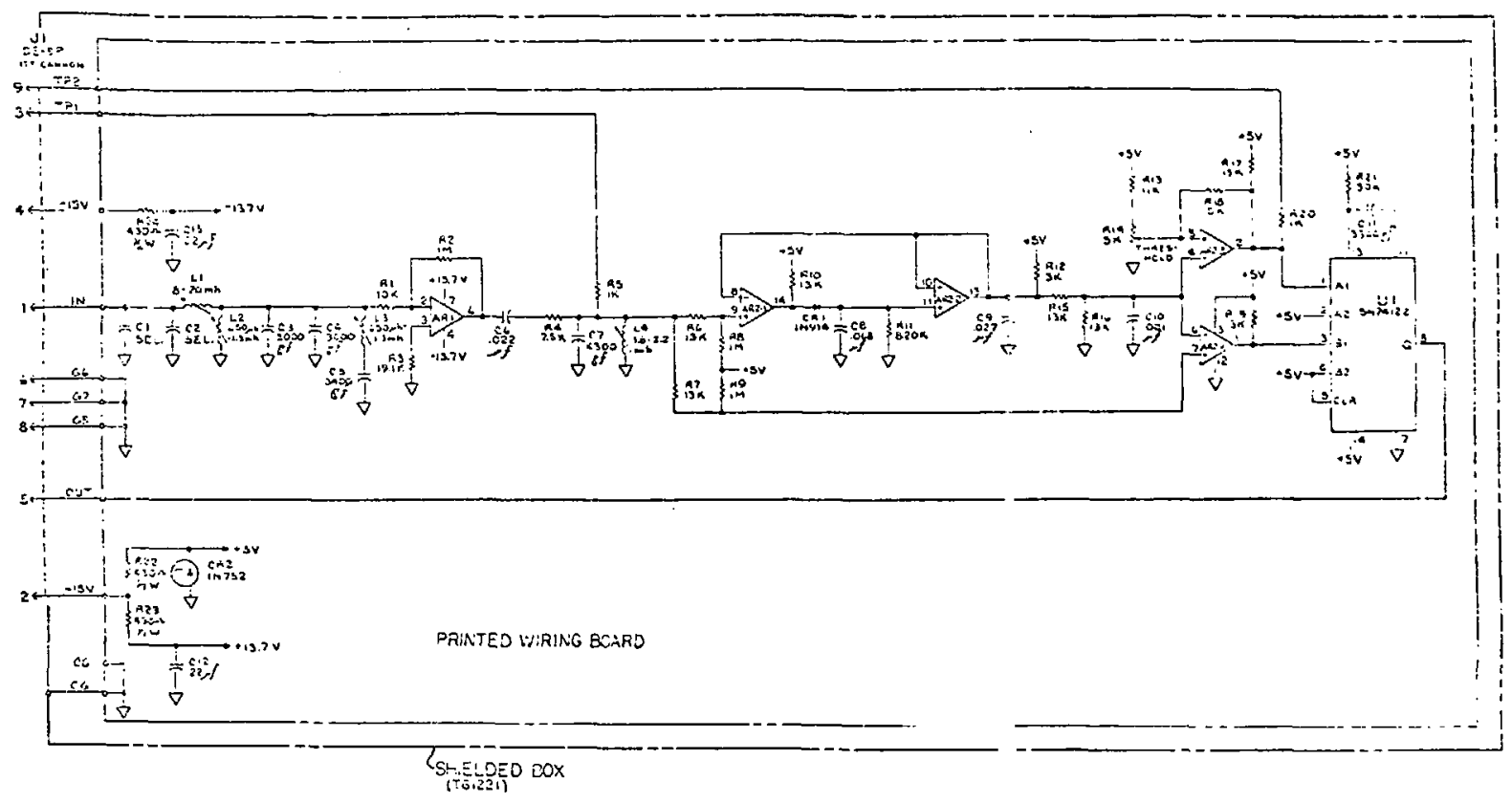

Figure 5. Schematic, Portal Filter/Demodulator 


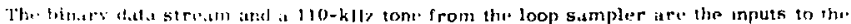

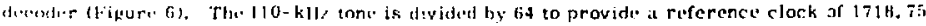
pulses per second which is the same as the credential hit rate and whith is synci.ronizcit with the

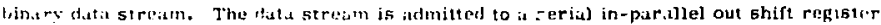
(Hegister 1 ) hater control of the-clock. The serial output of Hegister 1 is clocked into kegister 2. afld after +4 -hit periods, hoth rigisters may cun. in the same pattern of 24 bits. The 16 bits in Eith regiater which may represent thr HU-code are parillel outputed to a comparator. Thr. haritus of bits 2 through 9 ind hits 14 through 21 a re computed, anit unless hoth sets of th[?suljords have even parily the datia valid signal from the error detector is inhibited. Sinultunduss y with this hit compirison and parity cherk jroces, the parallal 16-bit oulputs from both jegisters are ah ched to sur. if fixed sync bits in positions 2 and 14 itre respectively 1 and 0. A syne bit ervor in either of the two words inhithits the data valid signal. The datia valid signal is sent to thr aperations cenrer only if hoth HD-corte groups puss the syne checks and the purity clecek. The diata vilits sigual also transfers the compiarator output to a holding register to await i) tranerisission ruquest from thi: operitious center. If the checking process is not succesful, thic prociss simply continu's at the rlock rate until either id data valid signal is generated or the r redutiul is wilduraw. Thr mimimun time required for checking is 48 hit periods or about 28 its. Ifuwrier, the syme and parity lits may not be in their correct bit positions initially and 23 bit preriorts must be illowid to shift thrm from the most extreme wrong position. Another

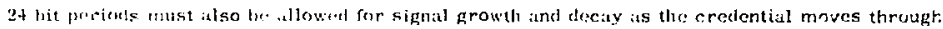

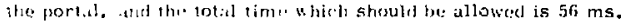

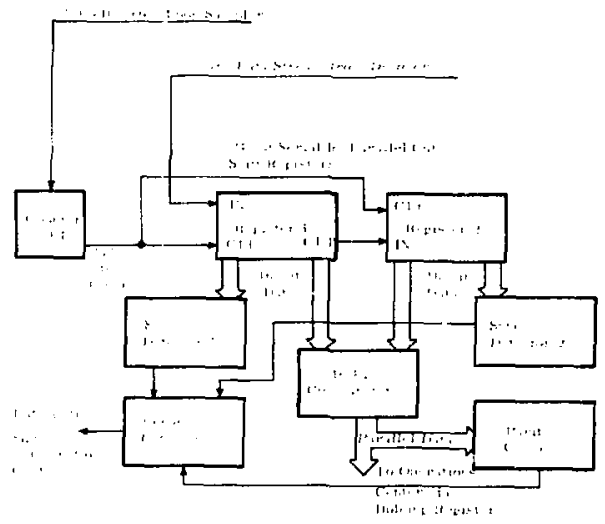

Higure 6. Block Diagram, Decoder 


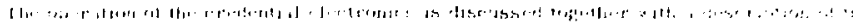

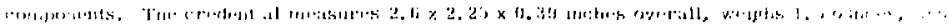

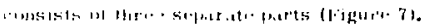

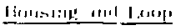

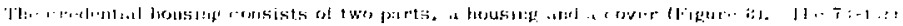

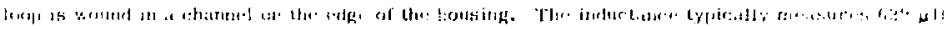

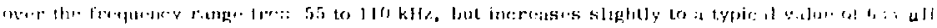

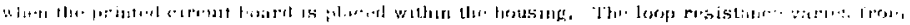

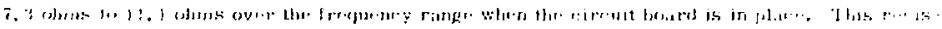

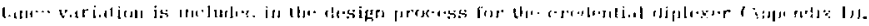

\section{(110.tat ithitril}

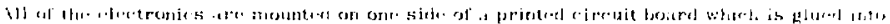

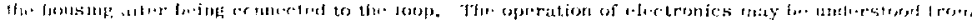

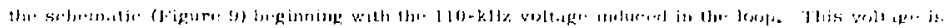

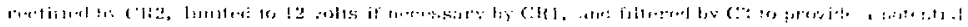

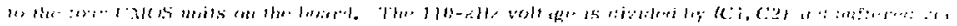

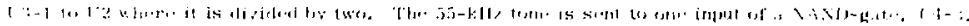

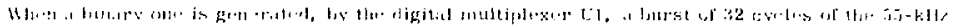

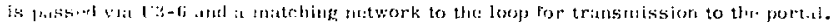
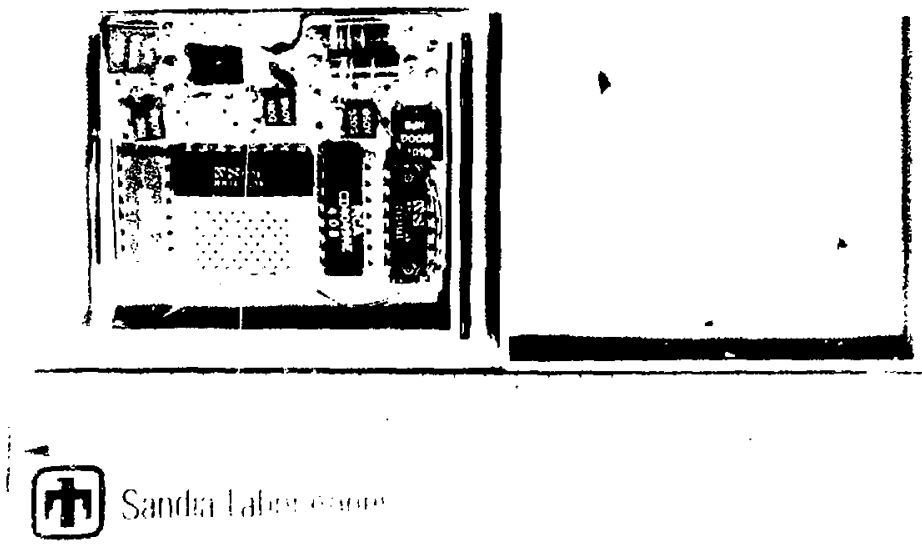

Figurs 7. licetronic Ciecientia! 


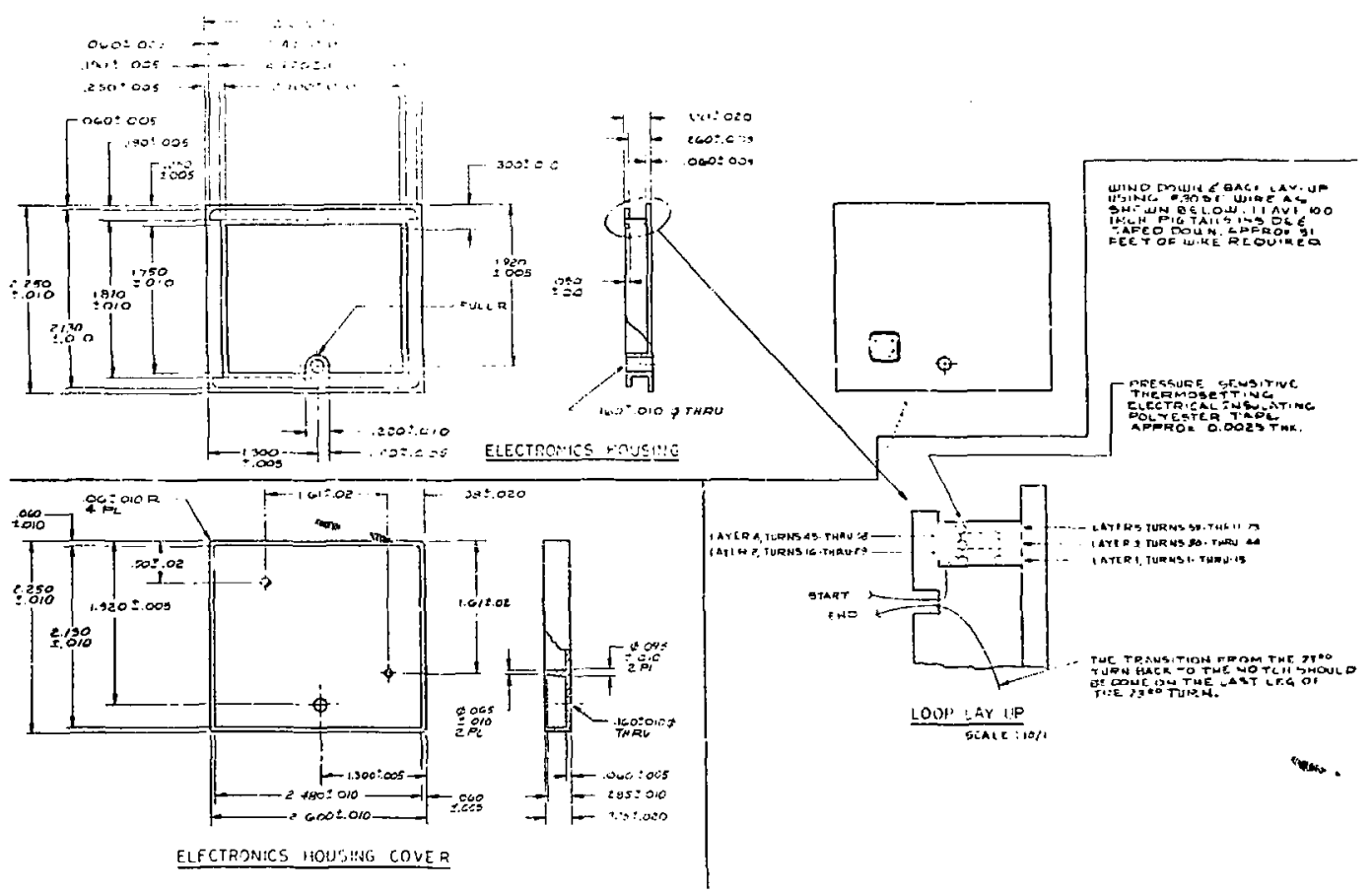

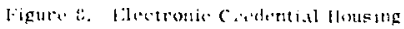



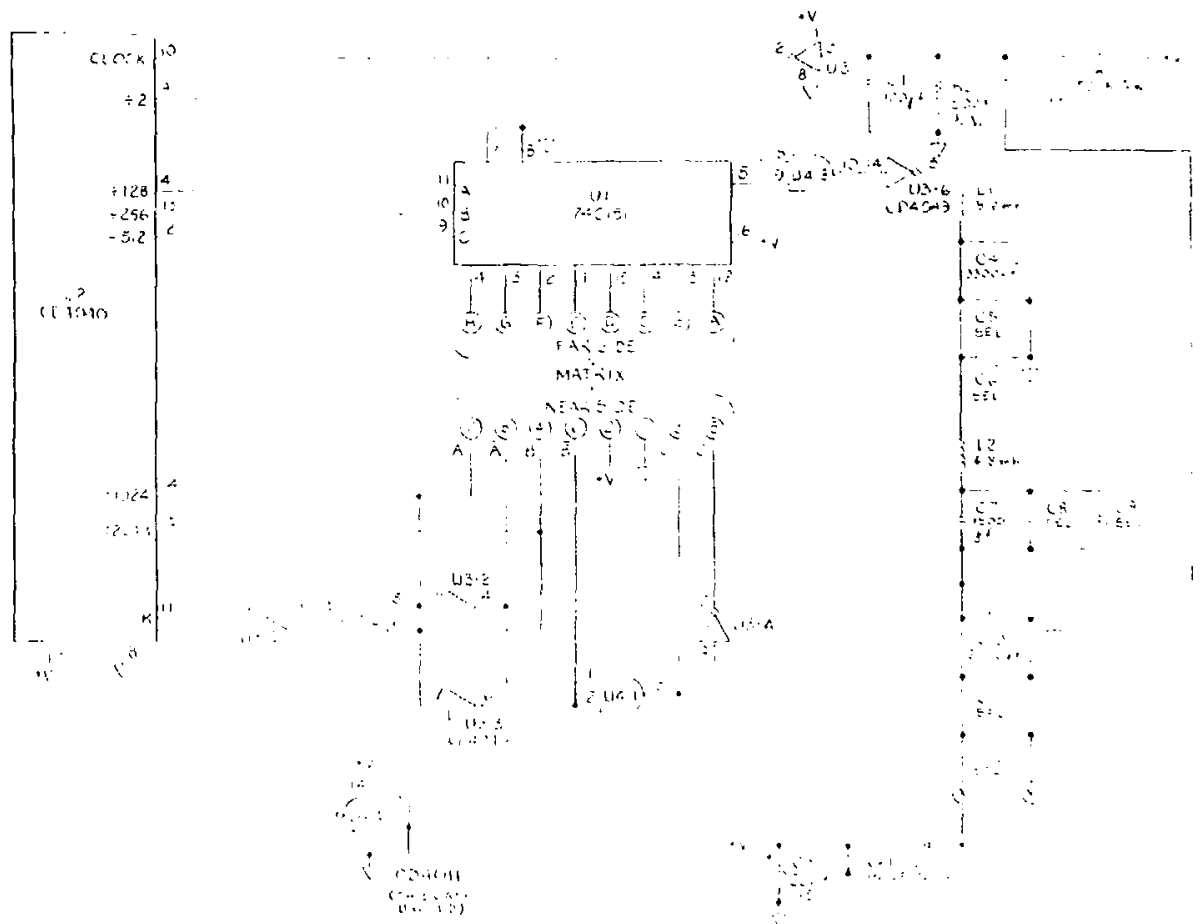

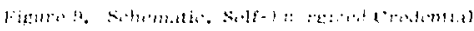




\section{Cods Storage ind Generation}

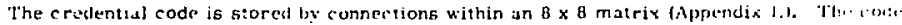

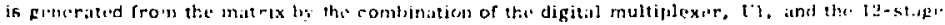

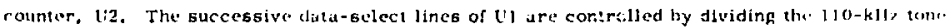
by 128, 256, and 512 respictively. The complimentary legie within Ul causes the dat: input linis to be suceesenely selected at it rate of $110 \mathrm{kH}$, divided by 64 , and thus establish the crielantial

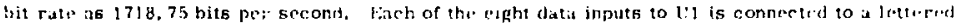
colusin of the matrix, and the rows of the atatix are activated by colling sigmals from 1.2 . In

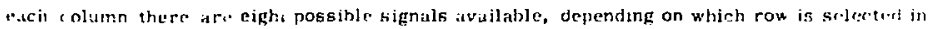

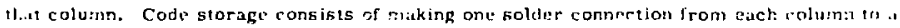
jurticular row un that column.

The cotling signais upon the matrix rows art generated from the 10th and 11 th slagks of $1: 2$

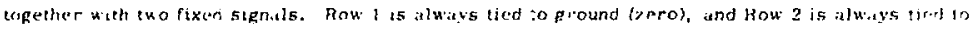

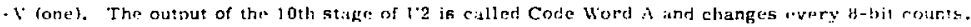

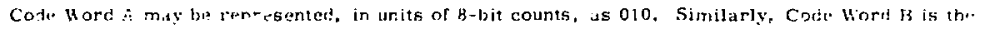
nutput of the 11 th stage of 22 and rupresemed is nol. Clearly, it is nucessary to rrset l:2 evi:ry

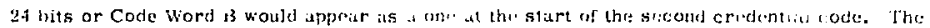

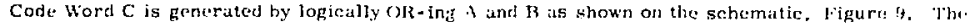
following talutition illustr.tes the digitil represontition associtated with each codi. word.

\begin{tabular}{|c|c|c|c|c|c|c|c|c|}
\hline \multirow{2}{*}{$\begin{array}{r}8-B i t \\
\text { Intervil } \\
\text { Numiser } \\
\end{array}$} & \multicolumn{8}{|c|}{ Code hurr and altrix hou Nu:nber } \\
\hline & Gndi1) & $V^{\prime}(2)$ & $\underline{x(7)}$ & $\overline{\mathrm{i}}(B)$ & $\underline{\bar{B}}(4)$ & $\underline{B(\tilde{a})}$ & $C(3)$ & $\vec{c}(\vec{s})$ \\
\hline 1 & 0 & 1 & : & 1 & 1 & 0 & s & i \\
\hline 2 & 0 & 1 & 1 & 0 & 1 & 0 & J & 1) \\
\hline 1 & 0 & 1 & 0 & 1 & 0 & 1 & 1 & 0 \\
\hline
\end{tabular}




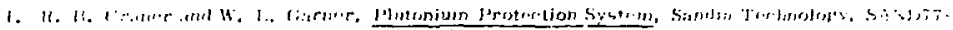

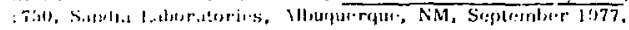

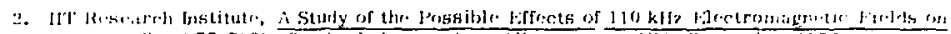

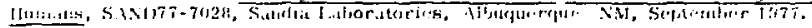

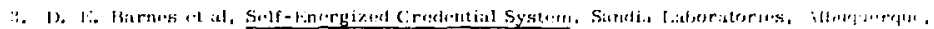

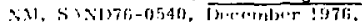


MIIIXIX)

Bminguous conles

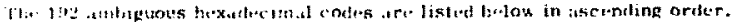

\begin{tabular}{|c|c|c|c|}
\hline $4(: 11)$ & 11074 & $\cos (\mathrm{s})$ & $(-1): 4$ \\
\hline$(-21)$ & 11075 & (2)31) & $13 \times 5$ \\
\hline$(4.4)$ & 6176 & C.51) & $t+\theta_{i}$ \\
\hline $1 \cdot-1)$ & 1177 & $(-51)$ & 1137 \\
\hline $130^{\circ}$ & 175 & Ixis: & $1: 4$ \\
\hline 1):0: & 175 & Ix: & $1 \%$ \\
\hline $\int_{i+1}$ & 170 & listo & $1 \%$ \\
\hline \multirow[t]{2}{*}{ :18:76" } & 177 & Ciste: & $1: 7$ \\
\hline & 274 & & 204 \\
\hline$(1: 3:)$ & 27.7 & Jot: ! & 3 \\
\hline 13:31 & $2: 3$ & lalls & $24 t$ \\
\hline ris: & 277 & SAl & 197 \\
\hline Hisl & $8 \pi$ & 8714 & 1349 \\
\hline$\because \cdots 1$ & 37.5 & 211 & $\because 1 \overline{1}$ \\
\hline $2 \div-3 \mid s$ & $37 i$ & $011:$ & $3 \%$ \\
\hline \&is & 157 & $\$ 7:$ & $2: 87$ \\
\hline 4.314 & +70 & 9711 & 1.10 \\
\hline $13 \%$ & 471 & $=18$ & J:3 \\
\hline 134 & 172 & 113 & 1.12 \\
\hline inis & 17 & 97 & $4: 5$ \\
\hline 4 & 301 & $\therefore 7: 4$ & $3,3 H_{i}$ \\
\hline $1 \because: 8:$ & 571 & $1: 18$ & 531 \\
\hline $14:{ }^{\prime}$ & 572 & 131 & $5: 32$ \\
\hline lis: & 17.1 & 1378 & 533 \\
\hline W'⿺t? & 1.70 & B?: & 536 \\
\hline$C(: 1)$ & $67 !$ & $(\div)$ & 63 \\
\hline$(c: 1)$ & (i)2 & $(21)$ & $f ;: 32$ \\
\hline (S) & 6i: & $(-11)$ & $f+3$ \\
\hline CFH & 77 & C. & $7: 6$ \\
\hline$\prod_{10}$ & 771 & IDC: & $7: 31$ \\
\hline $10 \% 0$ & 772 & j) & $7 \because 2$ \\
\hline $\operatorname{lin}_{1} x$ & 77? & INAC & $72: 3$ \\
\hline \multirow[t]{2}{*}{ All: } & $i_{2} \mid$ & Bit) & 特: \\
\hline & ins: & & (13:3s \\
\hline ec:1) & $1: 7: 1$ & KE & 854 \\
\hline ( $(:: 1)$ & :מד & $\mid C 21$ & $35 B$ \\
\hline$(-2)$ & $\because \because 1:$ & $(41)$ & 93.3 \\
\hline$(n i 1)$ & :יוl1 & C7is & mis \\
\hline $1 \times 16$ & $47 ;$ & 1310 & 95.1 \\
\hline 1$)^{\prime}: 6$ & $\therefore-13$ & $1126:$ & 2513 \\
\hline Iisc: & 118 & Hoc & $13 B$ \\
\hline \multirow[t]{15}{*}{$\forall H_{t}$} & 116 & $\ln$ & 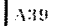 \\
\hline & 178 & & .54 \\
\hline & .375 & & .159 \\
\hline & 13111 & & 13:38 \\
\hline & $11: 4$ & & fH:S \\
\hline & 1578 & & $14: 8$ \\
\hline & 1379 & & {$[3.59$} \\
\hline & C.11 & & $\mathrm{CON}$ \\
\hline & $(2)$ & & C:31) \\
\hline & $\mathrm{C}+\mathrm{D}$ & & C.511 \\
\hline & $C 71$ & & Ciil \\
\hline & $1) 1 \mathrm{C}$ & & $130 \mathrm{C}$ \\
\hline & $152 C$ & & D.:C \\
\hline & $134 C$ & & $1 \mathrm{los}$ \\
\hline & H1.7C & & $\mathrm{FOGC}$ \\
\hline
\end{tabular}




\section{AIIINATX}

formalias for laveluest Volligk.

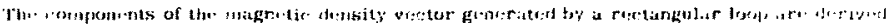

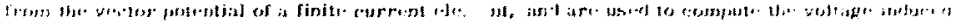

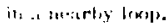

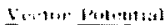

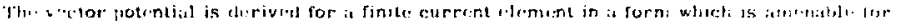

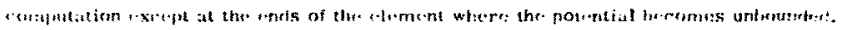

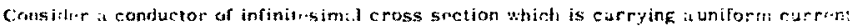

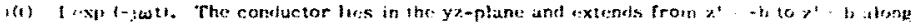

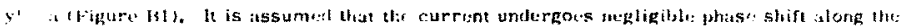

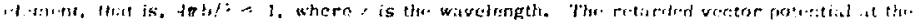

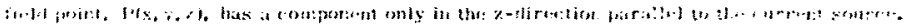

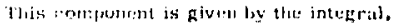

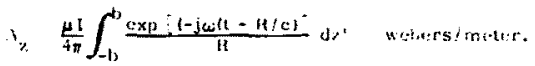

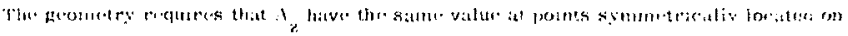

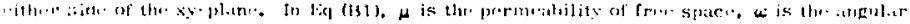

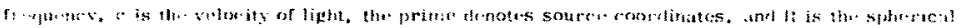

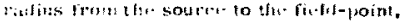

$$
\|\left\{\rho^{2}+\left(2-x^{2}\right\}^{1 / 2} \quad m+1 \cdot+s\right.
$$

$\because 1, \cdot 1$,

$$
0^{2} \quad x^{2}-(y-y)^{2} \quad \text { and }
$$

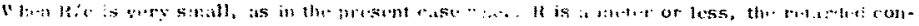
1, : bution is negrligihle :unes

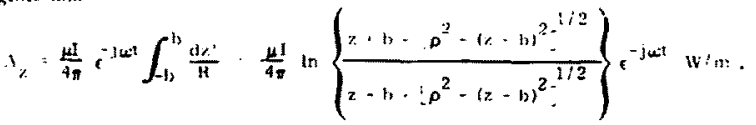


Il is not nuvious that $\mathrm{lig}([34)$ is symmetrical about \% : O, but symmetry ran bre shown is follows. Sulstituto -7 throughost liq (134) and requito the argument to that of lig (B4). cross multiply. simplify, and an identity will appear.

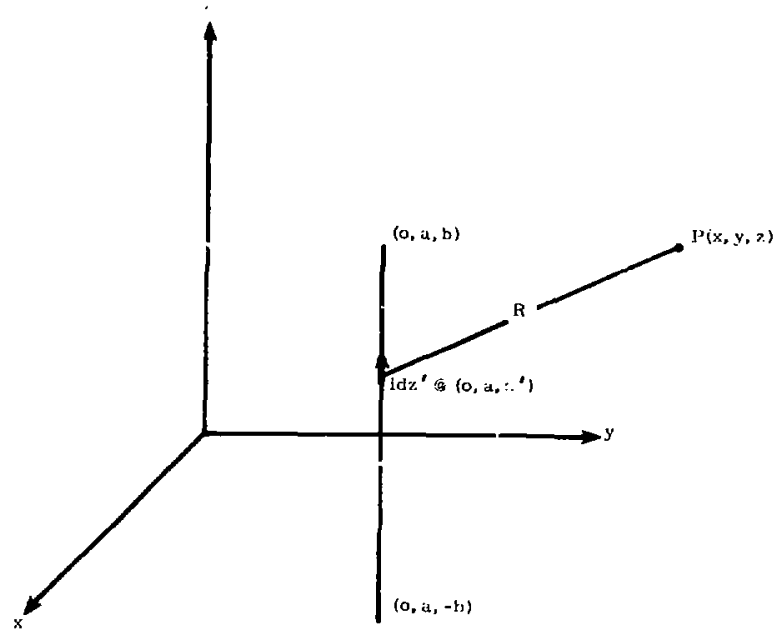

Figur. 131. Geometry of Curront Eilement and Ficles Point

When $\rho=0$ the definition of $R$ gives

$$
\left.R\right|_{\rho=0} \quad \%
$$

and the: vecior potential beeomes

$$
\therefore \sum_{\rho=0} \frac{\mu[}{4 \pi} \ln \left\{\frac{a b}{x-h} \mid\right.
$$

itrut

$$
\left.\lim _{x \rightarrow \infty}\right|_{\varphi=0} 0 .
$$

These results show that $\Lambda_{2} \geq 0$ everywhere but becomes unbounded at the nnds of the current element where $\beta=0$, and $\mid z_{1}^{\prime}=b$. 


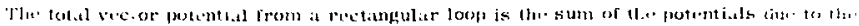

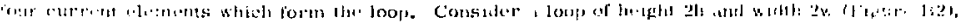

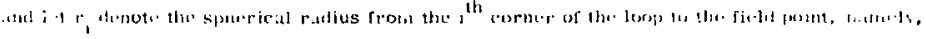

$$
\begin{aligned}
& r \cdot\left\{x^{2} \cdot(y+w)^{2}+(z-1,)^{2}\right\}^{3 / 2} \cdot r_{2} \cdot\left\{x^{2}+(y+n)^{2} \cdot(r \cdot 1)^{2}\right\}^{1+2}
\end{aligned}
$$

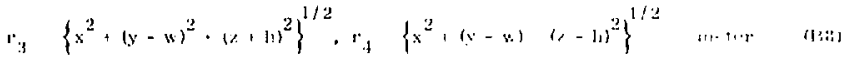
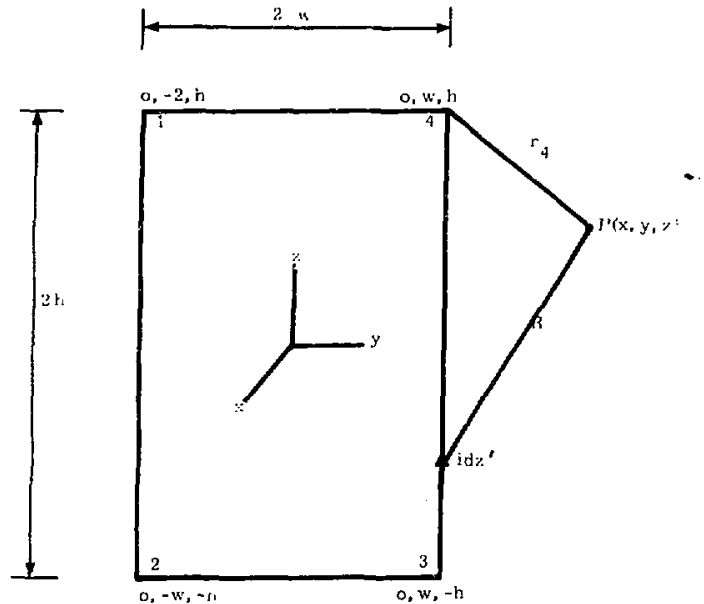

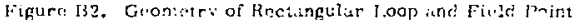

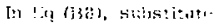

$$
\begin{aligned}
& y_{1} v_{2} \quad \because+k, r_{1} \quad \forall_{1} \cdot y-m \\
& { }_{1}-\gamma_{4} \quad z-h, z_{2} z_{3}-7 \cdot h
\end{aligned}
$$

to obtain the genersil form for the corner splueriral ratedus:

$$
r_{1}=\left\{x^{2}+y_{i}^{2}+z_{i}^{2}\right\}^{1 / 2}, i=1,2,3,4 .
$$


The components of the vector potential can now be wilten compactly by using Fe (BA) andt onitung the time depenctence (-xp $\{-$ jut $)$.

$$
\begin{aligned}
& A_{y}=\frac{\mu I}{4 \pi}\left\{\ln \left(r_{2}+y_{2}\right)+\ln \left(r_{4}+y_{4}\right)-\ln \left(r_{1}+y_{1}\right)-\ln \left(r_{3}+\gamma_{3}\right)\right\} \\
& A_{z}+\frac{\mu I}{4 \pi}\left\{\ln \left(r_{2}+z_{2}\right)+\ln \left(r_{4}+x_{4} \quad \ln \left(r_{1} \cdot x_{1}\right)-\ln \left(r_{3}+x_{3}\right)\right\} .\right.
\end{aligned}
$$

\section{Componenty of Mugnetio Density}

The mugnetic density vector is deriverl from thr vertor potential according to

$$
\bar{B} \cdot \operatorname{curl} \bar{\lambda} \text { Leslas. }
$$

The components rian be writtrn in thege compact forms:

$$
\begin{aligned}
& P_{x}=\frac{\mu 1}{4 \pi} \sum_{n}^{4} \frac{(-1)^{n}}{r_{n}}\left|\frac{y_{n}}{r_{n}+z_{n}}+\frac{{ }_{n}}{r_{n}+y_{n}}\right| \text {. } \\
& B_{y}-\frac{\mu[x}{4 \pi} \sum_{n=1}^{4}(-1)^{n+1} / \int_{n}\left(r_{n}+*_{n}\right) \\
& B_{z}=\frac{\mu I x}{4 \pi} \sum_{n=1}^{4}(-1)^{n} \mid\left\{r_{n}\left(r_{n}+y_{n}\right)\right\}
\end{aligned}
$$

\section{Indurecr.l Voliuge}

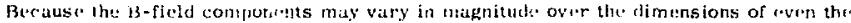
smaller loop. it is necessary to compute the induced voltagy as the dim. derivative of the averiese B-ficed normal to the plane of the loop which is locing induced. I.et the components of thu untt vector norinal to the surface of the induced loop be denoted by " $x$ " " $y$ " " $z^{\prime}$, and let " $s$ " be the areit per turn of llue $N$-tarn loop. The induced voltage is given by

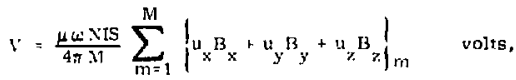

where $M-s e t=$ of field points are chosen within the urea of the loop. The use of $M=400$ for the credential loop and $\mathrm{M}=10,000$ for the portal loop, the points being equally saced in each case. has been sufficitent to provide uncertilintics of less than $c$. perecent. 


\section{$11 \cdot 1 \cdot 1: N I) C$}

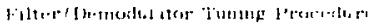

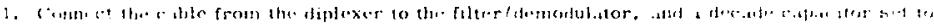

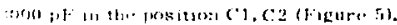

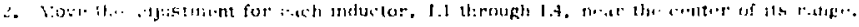

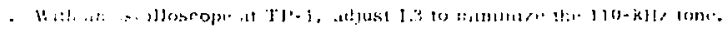

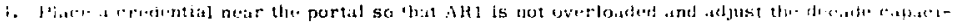

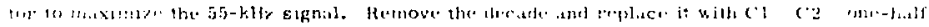

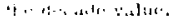

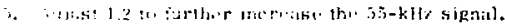

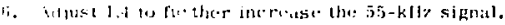

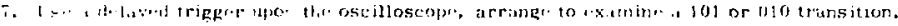

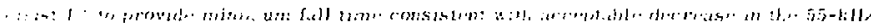
$1 \cdot \cdots \cdot 1$.

b. Herdyet 1.3 to improve rise: and full time:s if possible.

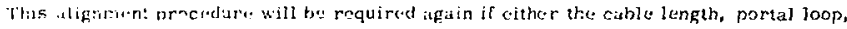

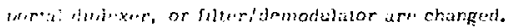


MII. S11:- 11

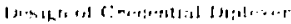

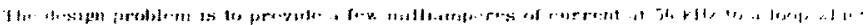

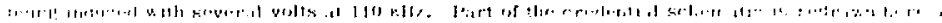

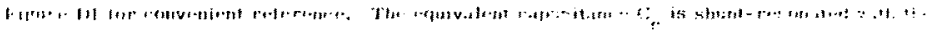

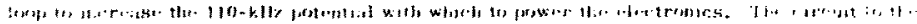

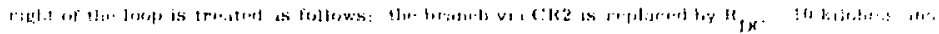

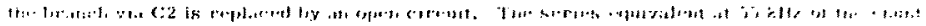

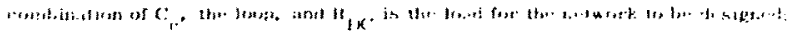

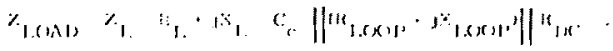

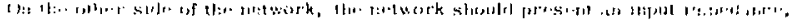

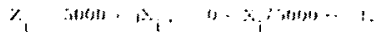

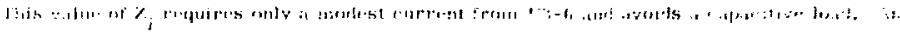

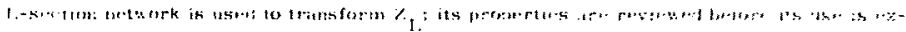
filititert.

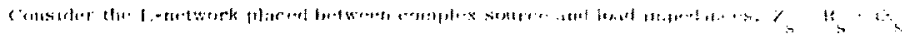

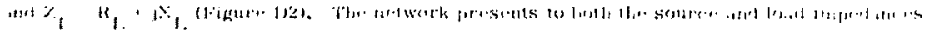

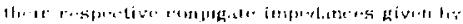

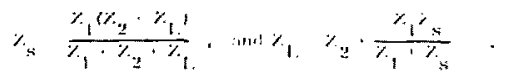

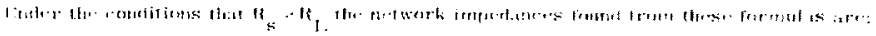

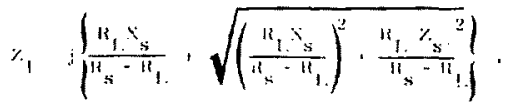

imal

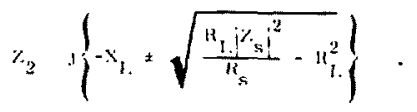




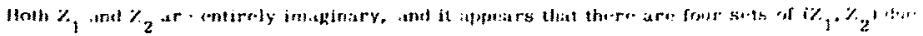

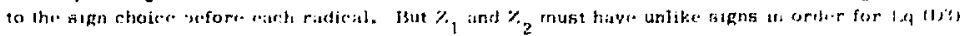
10 holf.

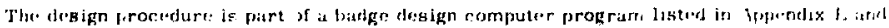
is sumsultitul as followa:

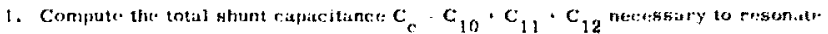
the loop intuctince at $110 \mathrm{ks} / \mathrm{x}$.

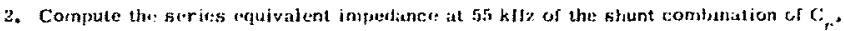
the loop, and $R_{\text {IJC }} \cdot 10,000$ ohms.

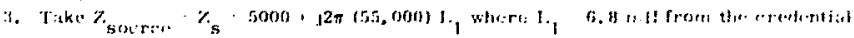

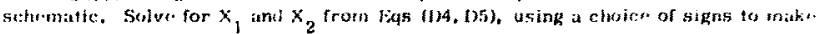

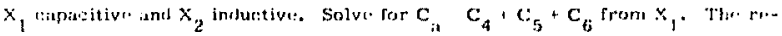

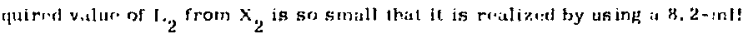
inductor ind sirries turing it by the proper rombination of $\mathrm{C}_{b} \quad \mathrm{C}_{7}+\mathrm{C}_{8} \cdot \mathrm{C}_{9}$.

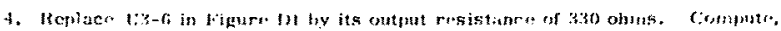

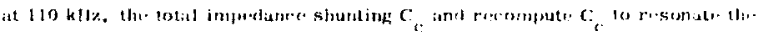
inpurdithes.

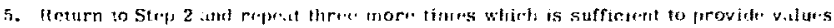

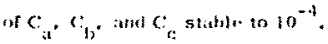

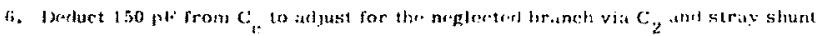

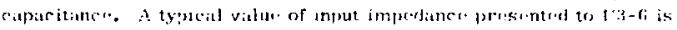

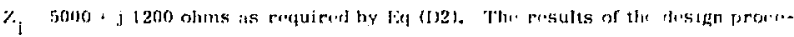

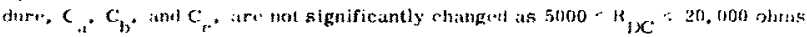

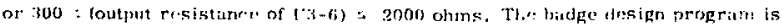

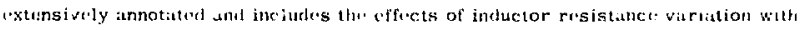
frequatey. 


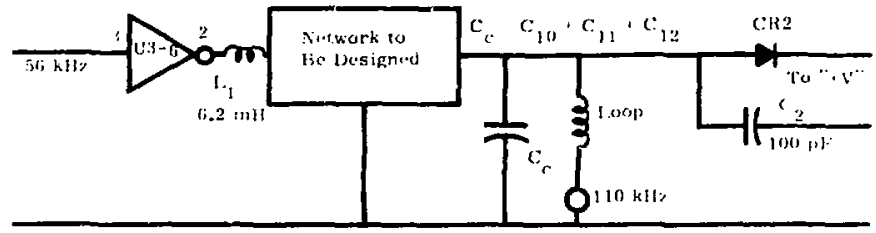

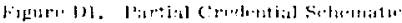

$$
\%_{1} \quad k_{1} \cdot i x_{2}, \%_{2}-k_{2} \cdot i x_{2}
$$

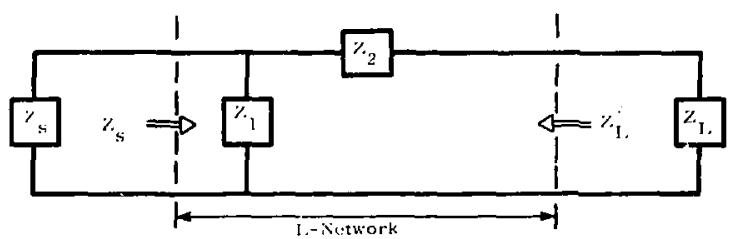

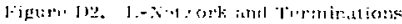




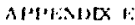

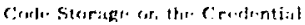

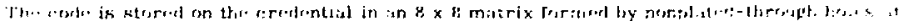

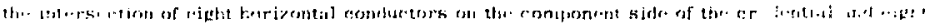

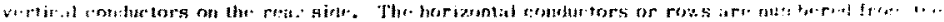

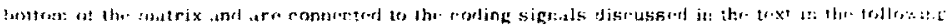

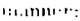

\begin{tabular}{|c|c|}
\hline Gordiny Signal & Afatrax lsow Wh. \\
\hline $\bar{\Lambda}$ & $y$ \\
\hline$\therefore$ & 7 \\
\hline$\overline{13}$ & $i$ \\
\hline$\overline{\mathrm{C}}$ & 5 \\
\hline$n$ & 4 \\
\hline$c$ & 3 \\
\hline iv & 2 \\
\hline (iND) & 1 \\
\hline
\end{tabular}

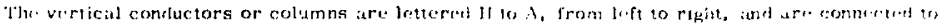

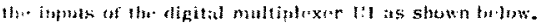

\section{Mlultiplinxror Injut.}

了

2

$\therefore$

i

5

Ii

7

8

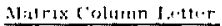

If

(i)

F.

I:

i)

C

is

$A$

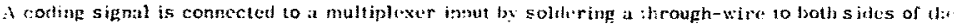

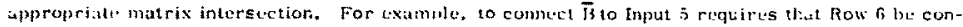
nected to Column D. A means must be provitled. prior to soldering, for represemtition ot the

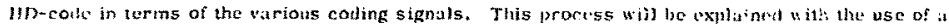
coling werkshect and an example. 


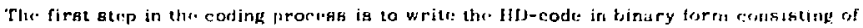

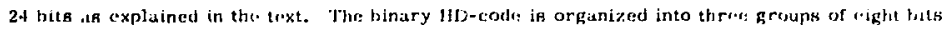

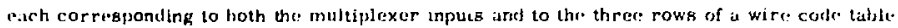
(Wigure la1). Curtuir bits which arc rixed are already filled in on the workshere. As an rexarmple consider the 1(5)-cods in the text, hA55, and fill in Step I of ligure li2. Step 2 ronsists of enter-

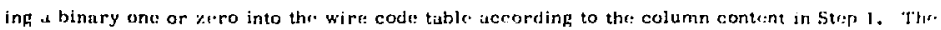
wire code is reas by column, from the top clown, converted to a matrix row number in Step 3 , and the row number is ligter for yach coiumn in Strep 4.

Copies of the blank worksheset may be used for cogling a small number of rer-diertials. Thr.

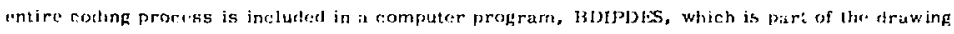
set $($ Apmentix $r)$. 

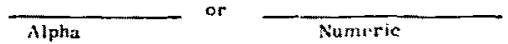

Step 1: Binary Represuritation fiven Parily

\begin{tabular}{|c|c|c|c|c|c|c|c|c|c|c|c|c|c|c|c|c|c|c|}
\hline Fit Position & 11 & 21 & 34 & 45 & 6 & 7 & 8 & $9 \mid 10$ & 11 & 1213 & 14 & $1 5 \longdiv { 1 6 }$ & 17 & 18 & $1 9 \longdiv { 2 0 }$ & $21] 23$ & $2 \mid 23$ & 24 \\
\hline Linary Code & 0 & 1. & & & & & & & 1 & $\underline{0}$ & 0 & & & & & & 1. & 1 \\
\hline \multirow{2}{*}{$\begin{array}{l}\text { Column } \\
\text { l.rettrer }\end{array}$} & 11 & G. & Ni & ED & c & B) & $\mathrm{A}$ & $11 \mathrm{G}$ & E) & $5: 13$ & $c$ & \begin{tabular}{l|l} 
& $\mathrm{A}$ \\
\end{tabular} & 11 & G & $F$ & 1) $\mathrm{C}$ & 11 & $\therefore$ \\
\hline & \multicolumn{7}{|c|}{ Row 1} & \multicolumn{5}{|c|}{ Row 2} & \multicolumn{6}{|c|}{ How 3} \\
\hline
\end{tabular}

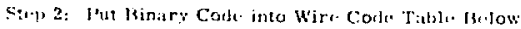

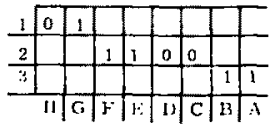

Step 3: Convert Wir Cocte to Matriy How Number

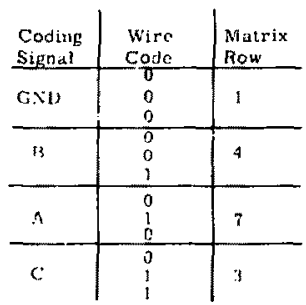

\begin{tabular}{c|c|c}
$\begin{array}{c}\text { Coding } \\
\text { Signal }\end{array}$ & $\begin{array}{c}\text { Wire } \\
\text { Code }\end{array}$ & $\begin{array}{l}\text { Matrix } \\
\text { Row }\end{array}$ \\
\hline$\overline{\mathrm{C}}$ & $\begin{array}{l}1 \\
0\end{array}$ & 5 \\
\hline $\bar{A}$ & 0 & \\
\hline$\overline{\mathrm{E}}$ & 0 & 8 \\
\hline $\mathrm{V}$ & 1 & 8 \\
\hline & 1 & 6 \\
\hline & 1 & 2
\end{tabular}

Sutp it Connet Colum to kow in Crodential Matrix

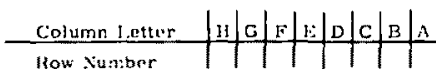

Figure jil. Credential Code Workshect, Blask 


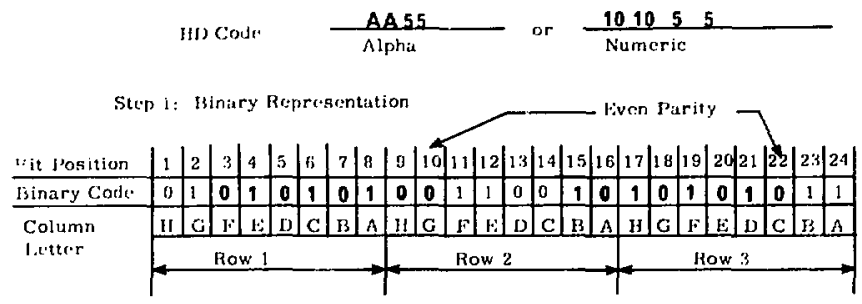

Step 2: Jut Pinary Code into Wire: Code. Table: Bclow

\begin{tabular}{l|l|l|l|l|l|l|l|l}
\cline { 2 - 8 } 1 & $f$ & 1 & 0 & 1 & 0 & 1 & 0 & 1 \\
\hline 2 & 0 & 0 & 1 & 1 & 0 & 0 & 1 & 0 \\
\hline 3 & 1 & 0 & 1 & 0 & 1 & 0 & 1 & 1 \\
\hline II & $C$ & $F$ & & 1 & 1 & $C$ & $B$ & $A$
\end{tabular}

Strip 3: Convert Wire Code to Matrix Row Number

\begin{tabular}{|c|c|c|}
\hline $\begin{array}{l}\text { Coosing } \\
\text { Signal }\end{array}$ & $\begin{array}{l}\text { Wire } \\
\text { Code }\end{array}$ & $\begin{array}{c}\text { Mintrix } \\
\text { Row }\end{array}$ \\
\hline (iNI) & $\begin{array}{l}0 \\
0 \\
0\end{array}$ & 1 \\
\hline IS & $\begin{array}{l}0 \\
0 \\
1\end{array}$ & 4 \\
\hline$\therefore$ & $\begin{array}{l}0 \\
1 \\
0\end{array}$ & 7 \\
\hline C & $\begin{array}{l}0 \\
1 \\
1\end{array}$ & 3 \\
\hline
\end{tabular}

\begin{tabular}{|c|c|c|}
\hline $\begin{array}{l}\text { Coding } \\
\text { Signill }\end{array}$ & $\begin{array}{l}\text { Wire: } \\
\text { Code }\end{array}$ & $\begin{array}{l}\text { Mutrix } \\
\text { lRow }\end{array}$ \\
\hline$\overline{\mathrm{C}}$ & $\begin{array}{l}1 \\
0 \\
0\end{array}$ & 5 \\
\hline $\bar{\lambda}$ & $\begin{array}{l}1 \\
0 \\
1\end{array}$ & B \\
\hline$\overline{19}$ & $\begin{array}{l}1 \\
1 \\
0\end{array}$ & 6 \\
\hline$+V$ & $\begin{array}{l}1 \\
1 \\
1\end{array}$ & 2 \\
\hline
\end{tabular}

Stup 4: Connoct Column to Row in Ciredential Matrix

\begin{tabular}{l|l|l|l|l|l|l|l|l|l} 
Column leetter & $H$ & $G$ & $F$ & $F$ & D & $C$ & $B$ & $A$ \\
\hline Row Number & 4 & 5 & 3 & 6 & 4 & 5 & 3 & 8
\end{tabular}

lifure $: 2$. Credontial Code Workshede with Example 


\section{AH'FEMA F}

I.15t of 13r:allitgs

Irawing Xumber - Issu*

\begin{tabular}{|c|}
\hline$(1+15+3-11$ \\
\hline $11+52+13$ \\
\hline 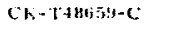 \\
\hline Itarsid-c \\
\hline [1]-T+HGSt- \\
\hline () $)-1+44,55-1101-C$ \\
\hline $55-[48650-13$ \\
\hline$T+19350-13$ \\
\hline $145131-11$ \\
\hline$C: r_{5}-1910: 51-13$ \\
\hline $1: 1,1: 1-1$ \\
\hline$x, 1012-1$ \\
\hline $9.1019-.3$ \\
\hline 75:01t-i \\
\hline T.31t!5-3 \\
\hline$T 51016-1$ \\
\hline $151017 \cdot 13$ \\
\hline $151018-11$ \\
\hline $105+100 \cdot 1$ \\
\hline$(7-7.2 \geq+1-;$ \\
\hline $178.1527 \cdot .1$ \\
\hline$F .364 .28-13$ \\
\hline $5+1221=$ \\
\hline $1+1222-i$ \\
\hline 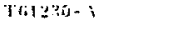 \\
\hline
\end{tabular}

Hite.

$1.0 \times 1+-1 \mu_{1} l_{1} \times t^{2}+2$

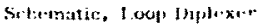

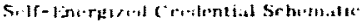

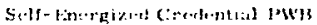

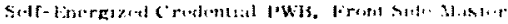

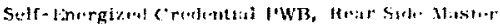
Jrogram BIJPLES

l.oop Driver, Itwr Amp Vacior Bond

isst:mbly, loop briver

Sebe-nlatie. fortal loop firtwer

Brirket, Capurtor

lsrilkket, Coil

luvirer Supply afounting Wrackot .

lowir Transistor Nounting Cover

Fronl laner

Irinsformer Wounting Jratklat

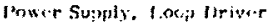

Printed Wirirg isscmbly, loop briver

t:Aectronic Crotemisl flousing

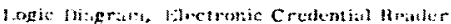

Stheratic, Portal Filter/Denotulitor

Assembly, a retentiul

Filer/ldemoluletor Box

Filler/formotulatur hssembly

soch, Siatminer 
l.S troputement of itherey (5) Wishungton, IX: 20si:,

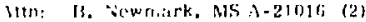
Salequards and Srecurits.

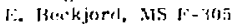

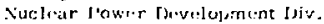
G. ()rtol. MS B-107 Wasite Misnigramint lJiv.

C. J. J'll:;t, AIS $3 ;-107$ idvant rel Systems $\lambda$ Matsirial '': orlucts joiv.

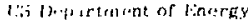

illucpurertur Opferations (uffica

1.0. $130 \times 5.400$

H)ueperque, $x: M \quad 871 \%$

litri: J. Ji. Cramt

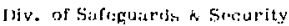

Nincleitr Ra:hdatory Commission

Wishingun, j) 205.t.

ittri: $\because$ J. Arsinatult [3iv. of sifregu ards, f'ur.] Cyr:le. k Finvirumont.al leostiareh

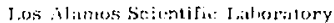

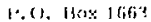

l.os iliraos, Nis] 117.45

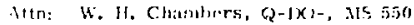

irgonta Sitional I aboritory

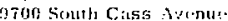

Ireonis, II, 904:35

litn: f. Prorsiand

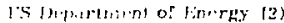

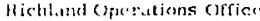

[', (). $[30 \times 5 \times 50$

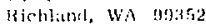

Ittn; K. I.. Jitekson Secerily $\&$ Sufoguartis

G. J. Mishko

Nucluitr Processing 13r.

inomies [nt crnalional Division (2)

lRorkwrll Ilanforl Operitions

5. O. 30x 800

Ricliland, wh 9035?

ittn: K. l:. tloinemar,

If. I. Stautlachior

1001 G. A. Powler

1500 W. A. G:Iriner

1580 T. S. Cliureh

1584 M. J. Navrutil (10)

1584 D. E. Matrnes

1584 T. W. H. Cafliny (10)

1700 W. C. Nyrt:

1 ilo V. E. Biakc, Ir.
$17: 11$

175

175,4

17.77

1758

1790

$[7 f]$

| 761

1762

1763

1755

1755

1400

4720

Goll

326fi

3141

अ151

C. H. Mitunity

J. E. Stivglat

J. F N N

v. F. Sinith

c. l: colsir

i. Jitcolss

I. $\lambda$, Seliers

J. Ireveney

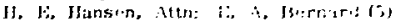

t. C., Waddoups

J). S. Miynsiti

W. K. Retair:

i. W. Snytrit

V. 1.. Jjugin

(i. C. Nowlin li:

b.. A. hist

j. Wernis (is)

W. I.. Ciarner (z)

For DCHFTIC (12atent Ciution)

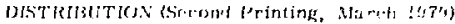

[5?.4 X, I. Xisuriti] (20)

1584 [D. H. 135rnes (15)

154.4 ?. W. 11. risfer 115$)$

1757 V. K. Simith (10)

befif J: A, Aas

$3[11$ T. 1., Werner (s)

3151 il. I. Siamer (a)

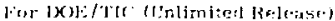

I $35: 1960$ (25)

132. I. ( 